\title{
Infection dynamics of two renal myxozoans in hatchery reared fry and juvenile Atlantic cod Gadus morhua L.
}

\author{
A. S. HOLZER ${ }^{1,2 *}$, S. STEWART ${ }^{1}$, A. TILDESLEY ${ }^{1}$, R. WOOTTEN ${ }^{1}$ and C. SOMMERVILLE \\ ${ }^{1}$ Institute of Aquaculture, University of Stirling, Stirling FK9 4LA, Scotland, UK \\ ${ }^{2}$ Cavanilles Institute of Biodiversity and Evolutionary Biology, University of Valencia, P.O. Box 22085, 46071 Valencia, \\ Spain
}

(Received 23 December 2009; revised 26 Fanuary 2010; accepted 27 Fanuary 2010; first published online 26 May 2010)

\begin{abstract}
SUMMARY
In order to study the infection dynamics of 2 renal myxozoans, Zschokkella hildae Auerbach, 1910 and Gadimyxa atlantica Køie, Karlsbakk and Nylund, 2007 in cultured Atlantic cod, Gadus morhua L. aged 3-19 months, a specific single-round PCR assay and a double-label in situ hybridization protocol were developed. The results demonstrated that the 2 myxozoans show spatial separation of their development with regard to spore formation inside the renal tubules versus the collecting ducts and ureters, as well as temporal separation with $Z$. hildae proliferating and developing spores only once the G. atlantica infection decreases, despite the presence of both myxozoans in the smallest fry studied. These results strongly suggest within-host competition of the 2 myxozoans with potential suppression of $Z$. hildae by $G$. atlantica until G. morhua acquires immunity against $G$. atlantica. The quantification of the G. atlantica infection inside the renal tubules before and after a 29-day experimental growth performance study using fry from hatcheries with differing filtration systems showed that the intensity of infection with $G$. atlantica seems to be controlled if prolonged exposure to the myxozoan transmission stages takes place from hatching onwards. Surprisingly, growth rates in the trial were inversely affected suggesting that G. atlantica does not negatively influence cod fry growth performance.
\end{abstract}

Key words: Myxozoa, Gadimyxa atlantica, Zschokkella hildae, mixed infection, hatchery reared, dynamics, competition, innate and acquired immunity, double-label in situ hybridization, PCR.

\section{INTRODUCTION}

Two myxozoans, Gadimyxa atlantica Køie, Karlsbakk and Nylund, 2007 and Zschokkella hildae Auerbach, 1910, were detected in the excretory system of the kidney of Atlantic cod, Gadus morhua L. reared in a tank-based research facility on the Mull of Kintyre (Western Scotland) (Holzer et al. 2010) and it was thought possible that they may be associated with mortalities in $0+$ fry. Myxozoans are a large phylum of metazoan parasites with approximately 2200 known species (Lom and Dyková, 2006), occurring predominantly in fish but with only a small proportion reported to be pathogenic. However, several species that sporulate in the renal tubules cause severe pathologies resulting in mortalities of up to $100 \%$ of affected stocks e.g. Tetracapsuloides bryosalmonae Canning, Curry, Feist, Longshaw and Okamoura, 1999 (Feist et al. 2002; Wahli et al. 2002), Sphaerospora renicola Dyková and Lom, 1982 (summarized in Lom and Dyková, 1992) and Parvicapsula minibicornis Kent, Whitaker and

* Corresponding author: Holzer, Cavanilles Institute of Biodiversity and Evolutionary Biology, University of Valencia, P.O. Box 22085, 46071 Valencia, Spain. Tel: +34 9635 43685. Fax: +349635 43733. E-mail: astrid. holzer@uv.es
Dawe, 1997 (St Hilaire et al. 2002; Jones et al. 2003). The kidney is a common site of infection for myxozoans where there may be more than 1 species present. However, little is known about the dynamics and interaction of mixed myxozoan infections. To gain a better understanding of such infections, particularly with regard to host age, G. morhua of different age classes ranging from 3 to 19 months were analysed with regard to prevalence, intensity of infection and location of $G$. atlantica and $Z$. hildae. At the facility on the Mull of Kintyre the growth performance of ongrowing fish is variable to the extent that they are divided into 'good' and 'bad' performers and, as growth performance has an economic impact, it was of interest to assess this in relation to infection. G. morhua at this site are derived from 3 hatcheries which differ in the age of initial exposure of fish to the parasites depending on the filtration system used at each site.

There are inherent problems in studying mixed myxozoan infections using the same organ owing to the difficulty of discriminating early life stages for which there are, as yet, no defining morphological characters. The methodologies developed for this study, therefore, included a rapid screening technique for fish tissues using a single-round PCR assay detecting both myxozoan species, and, for the first time in this parasite group, the use of a combined 
Table 1. Number, size and origin of Gadus morhua studied for myxozoan infections

(*Indicates fry from the same batch of fish which were separated into 'good' and 'bad' performers with regard to survival and growth; mo=months, $\mathrm{Ex}=$ experimental fry subsequently grown on for 29 days to study growth performance in relation to the development of myxozoan infections.)

\begin{tabular}{llcll}
\hline \hline Number & Location & $\begin{array}{c}\text { Age (months)/ } \\
\text { average size }(\mathrm{cm})\end{array}$ & Performance & Date \\
\hline 20 & Site A & $3 / 5 \cdot 6-6 \cdot 3$ & Good & July 2007 \\
20 & Site B & $3 / 5 \cdot 8-6 \cdot 5$ & Good & July 2007 \\
20 & Site C & $3 / 2 \cdot 5-3 \cdot 1$ & Good & July 2007 \\
10 & Site D & $6 / 8-14$ & Mixed & Aug. 2004 \\
8 & Site D & $6 / 9-12$ & Mixed & Dec. 2006 \\
6 & Site D & $18 / 26 \cdot 5-28$ & Mixed & Dec. 2006 \\
15 & Site D & $6 / 9-14 \cdot 1$ & Bad* & July 2007 \\
15 & Site D & $6 / 15 \cdot 9-18 \cdot 4$ & Good* & July 2007 \\
10 & Site D & $19 / 30-34$ & Mixed & July 2007 \\
$201 \mathrm{Ex}$ & Site B & $3 / 4 \cdot 8-5 \cdot 2$ & Good & Feb. 2008 \\
$201 \mathrm{Ex}$ & Site C & $3 / 4 \cdot 1-5 \cdot 3$ & Good & Feb. 2008 \\
\hline \hline
\end{tabular}

(double-label) in situ hybridization, which allows for the identification, differentiation and localization of all stages of development of the 2 myxozoan species on the same tissue section.

\section{MATERIALS AND METHODS}

\section{Origin of $\mathrm{G}$. morhua}

A tank-based Atlantic cod research facility on the Mull of Kintyre $\left(55^{\circ} 25^{\prime} \mathrm{N}, 5^{\circ} 44^{\prime} \mathrm{W}\right)$ Site D, is regularly supplied with cod fry from 3 different hatcheries i.e. Site A in Argyll $\left(56^{\circ} 45^{\prime} \mathrm{N}, 5^{\circ} 51^{\prime} \mathrm{W}\right)$, Site B on the Isle of Man $\left(54^{\circ} 12^{\prime} \mathrm{N}, 4^{\circ} 33^{\prime} \mathrm{W}\right)$ and Site $\mathrm{C}$, on the Mull of Kintyre $\left(55^{\circ} 25^{\prime} \mathrm{N}, 5^{\circ} 44^{\prime} \mathrm{W}\right)$, adjacent to Site D. On arrival at Site D, the different stocks from the hatcheries are mixed and on-grown. All hatcheries use local sea water and have a different water filtration system: at Site A, fry were maintained in $10 \mu \mathrm{m}$ filtered water, at Site B fry were exposed to $1 \mu \mathrm{m}$ filtered water for 58 days and then transferred to unfiltered water, and at Site $\mathrm{C}$ fry were cultured in $10 \mu \mathrm{m}$ filtered water. At site D, the water was coarse filtered at approx. $60 \mu \mathrm{m}$.

\section{Sampling regime and methodology}

In July 2007, 20 fry, 90 days old, were obtained directly from each of the 3 hatcheries. For histology and in situ hybridization, 10 whole fry from each hatchery were fixed in $4 \%$ neutral buffered formalin after longitudinal incision of the abdominal cavity. Smears of skin, gills and kidneys of a further 10 fry from each hatchery were examined for the presence of parasites at $\times 400$ magnification. The kidney smears were then transferred individually to Eppendorf tubes containing $300 \mu \mathrm{l}$ TNES urea buffer (10 mm Tris- $\mathrm{HCl}$ (pH 8), $125 \mathrm{~mm} \mathrm{NaCl,} 10 \mathrm{~mm}$ ethylenediamine tetraacetic acid, $0.5 \%$ sodium dodecyl sulphate, $4 \mathrm{~m}$ urea) for DNA extraction.
Between 2004 and 2007, sixty-four cod aged 6 to 19 months were obtained from Site D where fry from all 3 hatcheries are mixed and on-grown. At this site, mortalities and reduced growth had been observed amongst $0+$ cod during summer months. In 2007, fish of the same lot had been graded according to their feeding and growth performance on site, and 15 representatives each of 'good' and 'bad' performers were sampled. From all fish, $4 \mu \mathrm{l}$ of blood were collected from the caudal vein after removing the caudal fin. Subsequently the blood was mixed with TNES urea for DNA extraction to test for early myxozoan stages in the blood. Fresh smears of various organ pieces were viewed at $\times 400$ magnification before they were used for DNA extraction and adjacent organ pieces were fixed for histology.

All fish were anaesthetized on arrival and processed immediately thereafter. The number, size and origin of Atlantic cod sampled at the different sites are summarized in Table 1.

\section{DNA extraction and design of a specific PCR assay}

All DNA extractions were performed according to a standardized phenol-chloroform protocol (Holzer et al. 2004) after digestion of the samples with $100 \mu \mathrm{g} / \mathrm{ml}$ proteinase $\mathrm{K}$ overnight at $55^{\circ} \mathrm{C}$. The extracted DNA was re-suspended in 50-10 $\mu \mathrm{l}$ of RNAse/DNAse-free water and left to dissolve overnight in a refrigerator.

Based on previously obtained $18 \mathrm{~S}$ rDNA sequences of $G$. atlantica and $Z$. hildae from fish from Site D (Holzer et al. 2010) two specific PCR primer pairs were designed in the variable regions of the $18 \mathrm{~S}$ rDNA region of the 2 myxozoans: GadiF 5'-GTAATAGCATGGAACGAACAGT-3' (current study) and GadiR 5'-AGGACCCGATTTAG'TACATTATTA-3' (current study) for G. atlantica (or related Gadimyxa species due to high sequence 
similarities), and ZHF 5'-GTTGCCACTTGTATGGTCAATTAT-3' (current study) and ZHR 5'-GAGACAGATCCTGAGTCACAGAGCA-3' (Holzer et al. 2010) for $Z$. hildae. All primers were tested to exclude self-complementary binding or primer dimers, and they were then applied in a single-round PCR assay in a final volume of $10 \mu \mathrm{l}$ containing $0.01 \mathrm{U} \mu \mathrm{L}^{-1}$ of Thermoprime Plus DNA polymerase and the related $10 \times$ buffer with $1.5 \mathrm{~mm}$ $\mathrm{MgCl}_{2}$ (ABgene, Epsom, UK), $0.2 \mathrm{~mm}$ of each dNTP, $0.5 \mathrm{~mm}$ of each primer and 50-100 ng of DNA. Cycling conditions were set to: 3 min initial denaturation at $95{ }^{\circ} \mathrm{C}, 35$ cycles of denaturation $\left(94{ }^{\circ} \mathrm{C}, 30 \mathrm{sec}\right)$, annealing $\left(60^{\circ} \mathrm{C}, 30 \mathrm{sec}\right)$ and elongation $\left(72{ }^{\circ} \mathrm{C}, 30 \mathrm{sec}\right)$, and a final elongation step of $3 \mathrm{~min}$ at $72{ }^{\circ} \mathrm{C}$. The PCR assay was used to test the DNA extractions of tissue and blood samples for the presence of the 2 myxozoans. Positive controls of fish containing morphologically identifiable spores of both myxozoans and negative controls containing DNA extractions of fins obtained from cod larvae hatched in $1 \mu \mathrm{m}$ filtered sea water (site $\mathrm{B}$ ) were included whenever PCR reactions were run.

\section{Identification of Gadimyxa species}

Due to very small differences in the $18 \mathrm{~S}$ rDNA of G. atlantica and a second Gadimyxa species, i.e G. sphaerica, Køie, Karlsbakk and Nylund, 2007, described from cod, the PCR primers GadiF and GadiR designed in this study are not able to differentiate between the 2 species. However, the amplicons produced with the primers GadiF and GadiR include 2 areas with $G$. sphaerica-specific inserts of 6 and 4 bases, respectively, and an additional 4 individual base changes between G. atlantica and G. sphaerica. In order to determine whether different infection ratios of the 2 Gadimyxa species were responsible for the differences in the intensity of infection detected in fish from different hatcheries in 2007, PCR products obtained using primers GadiF and GadiR on DNA templates of 3 individual fish from Sites B and C (samples from 2007) were cloned into the pCR $2 \cdot 1$-TOPO vector (TOPO TA Cloning Kit, Invitrogen). Twelve clones from each fish (total of 72) were sequenced and analysed for species identity.

\section{Histology and double-label in situ hybridization}

For histological examination and in situ hybridization (ISH), organs or whole fry were fixed for $24-48 \mathrm{~h}$ in $4 \%$ neutral buffered formalin, subsequently dehydrated through an alcohol series, transferred into xylene and finally into paraffin. Longitudinal sections of whole fry were cut in a region where the maximum surface area of the kidney was present, whereas organ pieces of larger fish were combined in paraffin blocks and were cut arbitrarily.
Six $\mu \mathrm{m}$ sections were fixed on $3 \%$ APES-coated slides for in situ hybridization and on uncoated slides for Giemsa staining.

For synchronous identification and localization of pre-sporogonic and early sporogonic stages of both, $Z$. hildae and $G$. atlantica in the same section, an in situ hybridization protocol, which uses 2 differently labelled probes targeting DNA of the 2 myxozoans in the sections, was designed and applied. The methodology of the double label protocol is based on the protocol of a single-label biotin-streptavidinhorseradish peroxidase detection system published earlier (Holzer et al. 2003) which was combined with a digoxigenin (DIG)-anti-DIG-alkaline phosphatase system. A biotin-labelled probe GadiR designed for Gadimyxa sp. (Table 2) was applied simultaneously with a DIG-labelled probe, in this case ZHR, designed for Zschokkella (Table 2) for hybridization to the same section. After mixing the differently labelled probes with the hybridization buffer, denaturation and hybridization were conducted and the biotin label was detected as described by Holzer $\mathrm{et}$ al. (2003). Following the use of the Vector VIP substrate (Vectorlabs, Peterborough, UK), sections were washed in distilled water and transferred into TBS $(\mathrm{pH}$ 7.5). Subsequently, sections were incubated with 1:5000 anti-DIG-alkaline phosphatase Fab fragments (Roche Diagnostics, Mannheim, Germany) in TBS $(\mathrm{pH} \mathrm{7.5)}$ for $2 \mathrm{~h}$ at room temperature or overnight at $6{ }^{\circ} \mathrm{C}$. Following a wash in the TBS ( $\mathrm{pH} 8 \cdot 0$ ), Vector Blue (Vectorlabs, Peterborough, UK) was used as a substrate to visualize the DIGlabelled probe according to the manufacturer's recommendations. After a rinse in distilled water, counterstaining was conducted in some cases using methyl green (Vectorlabs, Peterborough, UK) and the sections were dehydrated through an alcohol series and transferred through a xylene replacement, Citrosol (Panreac Quimica SAU, Spain), into a xylene-free mounting medium (modified acrylic resin, Panreac Quimica SAU, Spain).

\section{Comparison of infection and growth performance of fry from Site B and Site C over a 29-day period}

Fry source. In February 2008, cod fry, 87 days posthatch, were obtained from the hatchery at Site B and 84-90 days-post hatch fry from Site C. They were stocked into experimental tanks at Site D receiving only coarsely filtered $(60 \mu \mathrm{m})$ water from a source close to Site C.

An initial sample of 15 fish was removed from each source prior to stocking in experimental tanks in order to obtain data on source infection status. These fish were individually weighed and measured and processed for histology.

Experimental design and fish maintenance. After removal of the initial subsample $(n=15)$ of each stock, 
the remaining fish were randomly distributed in weighed batches of 10 into $8 \times 73 \cdot 5 \mathrm{~L}$ identical tanks. Six of the tanks were arranged in a randomized block design with 3 tanks $\times 50$ fish from Site B fry and 3 tanks $\times 50$ Site $C$ fry. Ambient temperature was $8 \pm 0 \cdot 5^{\circ} \mathrm{C}$. A fourth tank of each stock was supplied with heated water to elevate the temperature to $12 \pm 0 \cdot 5{ }^{\circ} \mathrm{C}$. These consisted of 1 tank $\times 37$ fish from Site $B$ and 1 tank $\times 36$ fish from Site $C$. The flow rate in all tanks was $0 \cdot 5 \pm 0 \cdot 1 \mathrm{~L} \mathrm{~min}^{-1}$. The fry were fed to satiation for 29 days on Biomar Bio-optimal Start $1.1 \mathrm{~mm}$ at $6 \%$ biomass per day using an automatic feeding system. All tanks were siphoned twice a day and solids were dehydrated and weighed. Moribund fish were sacrificed, weighed and measured and processed for histology.

Sampling and data collection. After 29 days of maintenance all fish were sacrificed by an overdose of benzocaine. They were individually weighed and measured prior to fixation in $10 \%$ neutral buffered formalin and processed for histology. Fixed samples were trimmed prior to blocking to obtain a standardized longitudinal section of the kidney inclusive of its total length and giving the maximum surface area of kidney. After processing, 2 adjacent $5 \mu \mathrm{m}$ sections of each fish were stained in Giemsa for parasitological analysis.

Parasitological analysis. Parasitological data were collected from a randomly selected subsample of 13 fish from each stock prior to the start of the trial and 10 fish from each of the 8 tanks after 29 days. Eighteen moribund fish were also examined. To estimate parasite intensity in each fish, sections were viewed under $\times 200$ and $\times 400$ magnification and all renal tubule sections were counted and recorded as either infected or uninfected. Although each tubule might have been sectioned more than once, the standardization of sections allowed for comparisons between fish. Two adjacent kidney sections per fish were counted using separate counters so as to remove any bias in the counts. Both counts were recorded and a mean taken for each fish. Any sections without a complete longitudinal section of the kidney were discarded resulting in a total of 28 fish of each stock at $8{ }^{\circ} \mathrm{C}$ and 10 fish of each stock at $12{ }^{\circ} \mathrm{C}$ being analysed at the end of the trial. Only parasitic stages with obvious, clear nuclear staining were counted and the number of parasite cells in the infected tubules was not taken into account. Thus, the relative percentage of infected tubules was calculated for each fish sampled. Individual sections of a subsample of the same paraffin blocks including 8 fish from each site and temperature regime were subjected to ISH to confirm the identity of the parasite stages.

Data analyses. Specific growth rates $\mathrm{SGR}=[(\mathrm{ln}$ end weight in $\mathrm{g}-\ln$ start weight in $\mathrm{g}$ )/experimental days $] \times 100$ for each fish in each tank were calculated and compared. Estimated food conversion ratio $\mathrm{FCR}=($ amount of feed given - waste feed removed $) /$ (increase in tank biomass + weight of mortalities) was calculated for each tank.

Parametric analysis was carried out using an independent value $t$-test or ANOVA on multiple groups. Where data sets did not conform to the assumptions of these analyses in terms of normality of distribution or homogeneity of variance, transformations using natural logarithm were performed and the data were again tested for conformity. Where data sets were unable to be transformed to a suitable form, non-parametric analysis was carried out using Mann Whitney or Kruskal-Wallis tests on multiple groups. Analysis was carried out on pooled replicates where appropriate for greater statistical robustness. The pre-determined alpha level for $P$-value significance in all tests was 0.05. Statistical tests were conducted using Minitab v13.32 (Minitab Inc.) or GraphPad InStat v3.01 (GraphPad Software, Inc). Only data from the replicated tanks held at $8{ }^{\circ} \mathrm{C}$ were statistically analysed; the $12{ }^{\circ} \mathrm{C}$ tanks were not replicated and data are reported as observations.

\section{RESULTS}

\section{Age and sample site-related differences in the myxozoan infections}

In fresh microscopic smears, spores $(n=20)$ of $G$. atlantica measured $8 \cdot 2-9 \cdot 2(8 \cdot 8) \mu \mathrm{m}$ in width, $6 \cdot 8-8 \cdot 2(7 \cdot 3) \mu \mathrm{m}$ in length, $5 \cdot 9-7 \cdot 0 \quad(6 \cdot 5) \mu \mathrm{m}$ in thickness, with a polar capsule diameter of $1 \cdot 7-2 \cdot 2$ (1.9) $\mu \mathrm{m}$ and a polar filament length of 11-19 $\mu \mathrm{m}$. The measurements obtained from $Z$. hildae have been reported by Holzer et al. (2010). Microscopically, $G$. atlantica was found to produce abundant disporous pseudoplasmodia containing maturing spores in fry and 6-month-old cod, whereas they were very scarce or absent in $1+G$. morhua. In contrast, $Z$. hildae plasmodia and maturing spores were not detected in fry $\leqslant 6$ months old, with small numbers present in some of the 6 -month-old fish and larger numbers in all $1+\operatorname{cod}$, where the infection was quite extensive in individual cases.

The specific single-round PCR assay designed in this study produced 2 PCR products, a $104 \mathrm{bp}$ band for $G$. atlantica and a $336 \mathrm{bp}$ band for $Z$. hildae (Fig. 1) and confirmed the microscopic observations. Fig. 1 shows the results of PCR reactions of DNA extracted from kidneys of some representative cod from different sites and of different ages (details in Table 1). The PCR results show the infection prevalence and indicate, semi-quantitatively, the intensity of infection. Fry became infected with both $G$. atlantica and $Z$. hildae at very early age as bands for both species are present in the kidneys of the smallest, 3-month-old fry. These fry already 


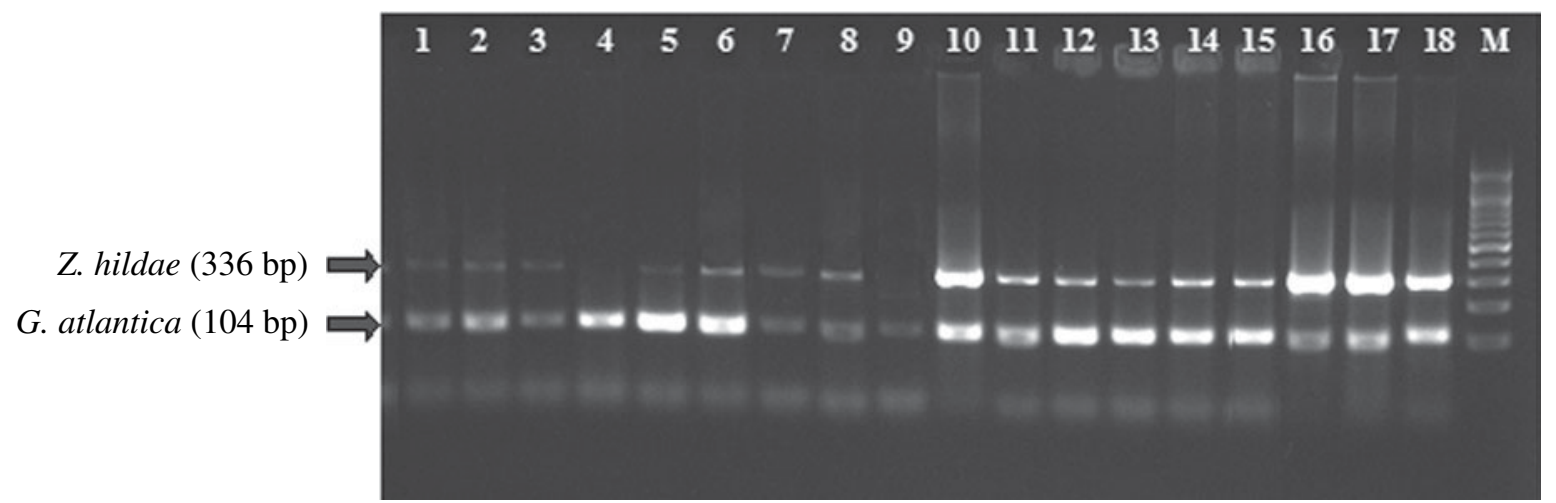

Fig. 1. Simultaneous PCR detection of Zschokkella hildae and Gadimyxa atlantica in Gadus morhua kidney extractions from different sites in Scotland. Representative samples of: $1-9=3$ month old G. morhua from 1-3: Site A, 4-6: Site B, 7-9: Site C; 10-15: 6 months old G. morhua from Site D with 10-12: 'Bad' performers and 13-15: 'Good' performers; 16-18: 19 months old G. morhua from Site D. M: size marker with bands every 100 bps.

presented a dominant $104 \mathrm{bp}$ ( $G$. atlantica) band, with fry from Site B showing a considerably larger amount of PCR product than those from Sites A and C. The highest amounts of G. atlantica PCR product were obtained from 6-month-old fry when compared with younger or older cod (Fig. 1). The oldest cod sampled (18 and 19 months old) showed a considerable decrease in the amount of $G$. atlantica amplicons. PCR bands of $Z$. hildae were very weak and sometimes absent in the smallest fry but PCR product increased in the 6-month-old fry and reached a maximum in the oldest (18 and 19 months old) cod. With regard to the presence or absence of PCR products of both species, no differences were detected between 'good performers' and 'bad performers' (Fig. 1). The quantities of $Z$. hildae PCR product were elevated in 7/30 fish (lane 10 of Fig. 1) when compared with other fish of the same age class, but this was independent of the performance status of the fish (3 'good performers', 4 'bad performers').

The considerably larger amount of $G$. atlantica PCR product detected in fry from Site B when compared with the other hatcheries (Fig. 1) raised the question of whether the difference in intensity of infection is due to different infection ratios between more than 1 Gadimyxa species. Sequences obtained from the analysis of 72 clones of PCR amplicons produced with the primers GadiF and GadiR from 3 fry from each of Sites B and C showed that all but 1 clone were identical with $G$. atlantica (compared with GenBank Accession numbers EU163412-21), with interclonal differences of no more than 1-2 bases. The clone that differed considerably ( 4 bases and 2 inserts of 4 and 6 bases, respectively) was obtained from a fry from Site $\mathrm{C}$ and was identified as G. sphaerica, identical with previously obtained $18 \mathrm{~S}$ rDNA sequences of this species (EU163424-5).

\section{Parasite location}

The PCR assay detected 18S rDNA of both $G$. atlantica and $Z$. hildae in kidney as well as in numerous other organs of infected fish, i.e. spleen, liver, heart, muscle, gills, brain and blood. PCR of DNA extractions from blood (Fig. 2) produced PCR products of $G$. atlantica in $56 \%(27 / 48)$ of the 6-month-old fry, whereas bands for G. atlantica were absent or, in exceptional cases, very weak in DNA extractions from blood of $1+\operatorname{cod}$ (lane 9 in Fig. 2). Blood samples were PCR-positive for $Z$. hildae in all the 6-month-old fry and in $62 \%(10 / 16)$ of $1+\operatorname{cod}$ (Fig. 2). Due to their small size and fixation on site, blood was not obtained from the 3-month-old fry and PCR data are thus not available. There was no difference in the presence or absence of blood stages of either myxozoan species when comparing 'good performers' and 'bad performers' but the amount of PCR product obtained from the blood samples was considerably higher in the cod sampled in the summer than in the winter (Fig. 2).

In situ hybridization (Fig. 3) confirmed the results obtained by PCR and added further information on the specific location of the 2 myxozoan species and the developmental stages present in fish of different ages and sites. Pre-sporogonic proliferative stages and spore-forming stages of $G$. atlantica were detected exclusively intratubularly, occurring in the proximal and distal parts of the renal tubules with the largest amount of parasite stages and numbers of tubules infected in 3-month-old fry. In some fry, pluricellular parasite stages of round to elongate shape and measuring $17 \cdot 5-41 \cdot 2 \mu \mathrm{m}$ in diameter were present in the kidney interstitial tissue but blood stages of $G$. atlantica were not detected on the sections using ISH despite positive PCR reactions from blood DNA extractions. Frequently, numerous small parasite stages consisting of cell doublets and measuring $8-13.5 \mu \mathrm{m}$ were detected in the glomeruli (Fig. 3C). In the oldest cod (18 and 19 months) the $G$. atlantica infection had almost disappeared and only isolated renal tubules were found infected with small numbers of this parasite. Despite the presence of weak PCR bands (Fig. 1), Z. hildae was not detected in sections of the smallest fry but multicellular 


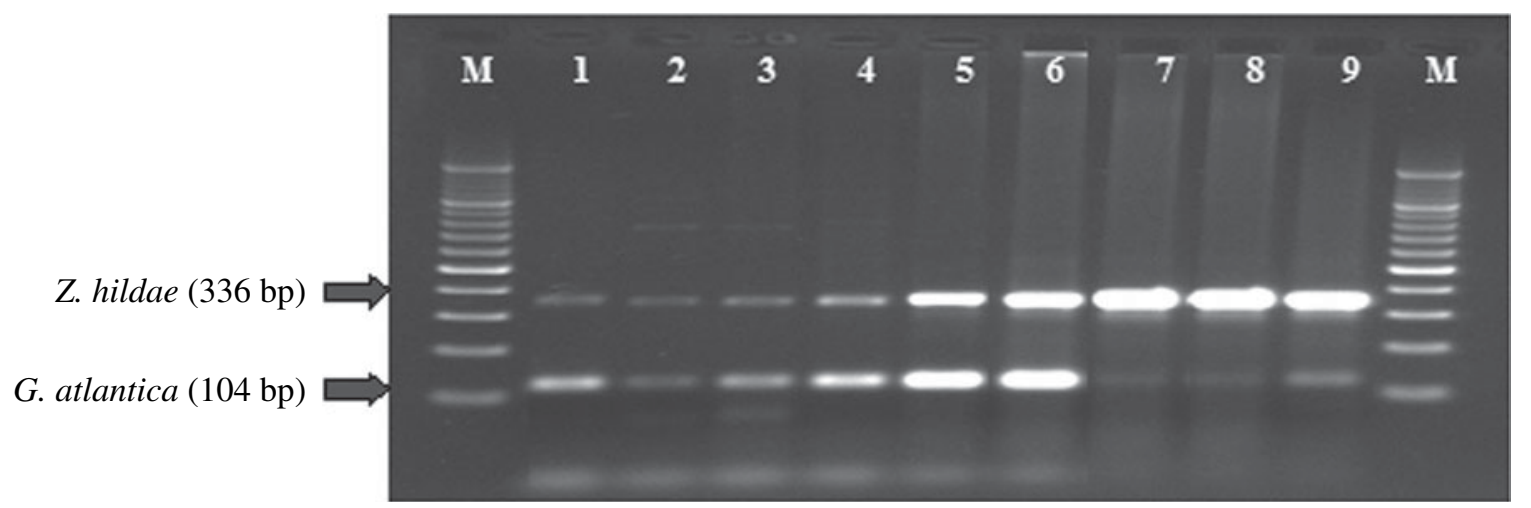

Fig. 2. Simultaneous PCR detection of Zschokkella hildae and Gadimyxa atlantica in blood samples of Gadus morhua. Representative samples of: 1-3: 6 months old G. morhua (Site D) sampled in winter, 4-6: 6 months old G. morhua (Site D) sampled in summer, 7-9: 19 months old G. morhua (Site D) sampled in summer. M: size marker with bands every 100 bps.

stages measuring $16 \cdot 4-35 \mu \mathrm{m}$ were found in the blood (Fig. 3D) and interstitial kidney tissue in some of the 6-month-old cod and in larger, sometimes very high, numbers in 18- and 19-month-old cod (Fig. $3 \mathrm{G})$. In some histological sections, interstitial stages of $Z$. hildae were found to invade the urinary collecting ducts by crossing the epithelium (Fig. 3E). Spore-forming stages of $Z$. hildae, first seen in 6 -month-old cod, were mainly found in the large collecting ducts and the ureters, which, in 18- and 19-month-old cod, were sometimes completely filled with Z. hildae stages (Fig. 3G). Occasionally, large parasite stages and spore-formation of $Z$. hildae were observed in the kidney interstitial tissue (Fig. 3F). No pathological changes were evident in kidneys with large numbers of intratubular $G$. atlantica stages or blood and interstitial stages of $Z$. hildae. However, collecting ducts heavily infected by $Z$. hildae showed invasion of macrophages into the epithelium of the collecting ducts (not shown), and detached pieces of the epithelial lining were detected amongst masses of spore-forming parasites, indicating epithelial sloughing presumably caused by the parasites (Fig. 3G).

$G$. atlantica infection dominated in histological sections of the 3-month-old fry, whereas in $1+\operatorname{cod}$, $Z$. hildae infection was more prominent, with only a small number of tubules harbouring residual
G. atlantica infection, confirming the PCR results. Thus, co-infection of the 2 myxozoans in the kidney was temporally restricted mainly to the 6-month-old G. morhua, where invasive blood and interstitial stages and, in some fish, also sporogonic stages of $Z$. hildae co-occurred with sporogonic stages of G. atlantica.

Comparison of infection and growth performance of
fry from Site $B$ and Site $C$ after 29 days of growth

The comparison of the development of the myxozoan infection parallel to the performance of the host was studied in fry from 2 hatcheries with different parasite loads, Site B and Site C (compare Fig.1), before and after a 29-day period of maintenance at 2 different temperatures, $8{ }^{\circ} \mathrm{C}$ and $12{ }^{\circ} \mathrm{C}$.

Fish growth and performance. The results of the parameters measured in the fish growth study are summarized in Table 2. The start weights of fry from Site B and C were not significantly different. The end weights of fry from the replicate tanks for each site maintained at $8{ }^{\circ} \mathrm{C}$ were pooled for analysis except the results from 1 replicate tank of site B (tank 3) which was excluded from further analysis as the fry were significantly larger than the other replicates and this was attributed to an unknown tank effect. Fry

Fig. 3. Simultaneous detection of Gadimyxa atlantica and Zschokkella hildae in histological sections of the kidney of Atlantic cod, using double-label in situ hybridization, with G. atlantica visualized in purple (Vector VIP substrate) and $Z$. hildae in dark blue (Vector Blue substrate); background staining in (C) and (G) is methyl green. (A) Intratubular sporogonic stages (ITS) and 1 interstitial, migratory stage (ISS) of G. atlantica in experimentally maintained $\left(8^{\circ} \mathrm{C}\right)$ Site $\mathrm{C}$ fry with average level of infection. (B) Increased infection with larger numbers of tubules infected with G. atlantica and sporogonic stages filling the tubules, experimental growth trial $\left(12{ }^{\circ} \mathrm{C}\right)$ Site B fry. (C) Glomerulus infected with cell doublets of G. atlantica, 3-month-old fry (non-experimental, Site C). (D) Invasive blood stages of $Z$. hildae amongst erythrocytes, 6-month-old cod (Site D). (E) Interstitial migratory stage (ISS) of Z . hildae, a parasite traversing (TS) the epithelium of the urinary collecting duct (CD) and spore-forming stages of $Z$. hildae inside the duct, 18-month-old cod (Site D). (F) Mass of cells of $Z$. hildae forming spores (S) in the interstitial tissue of the kidney, 18-month-old cod (Site D). (G) Ureter (UR) with masses of spore-forming parasites and detached elements (ES) of the otherwise intact epithelium (EUR) of the ureter, 19-month-old cod (Site D). 


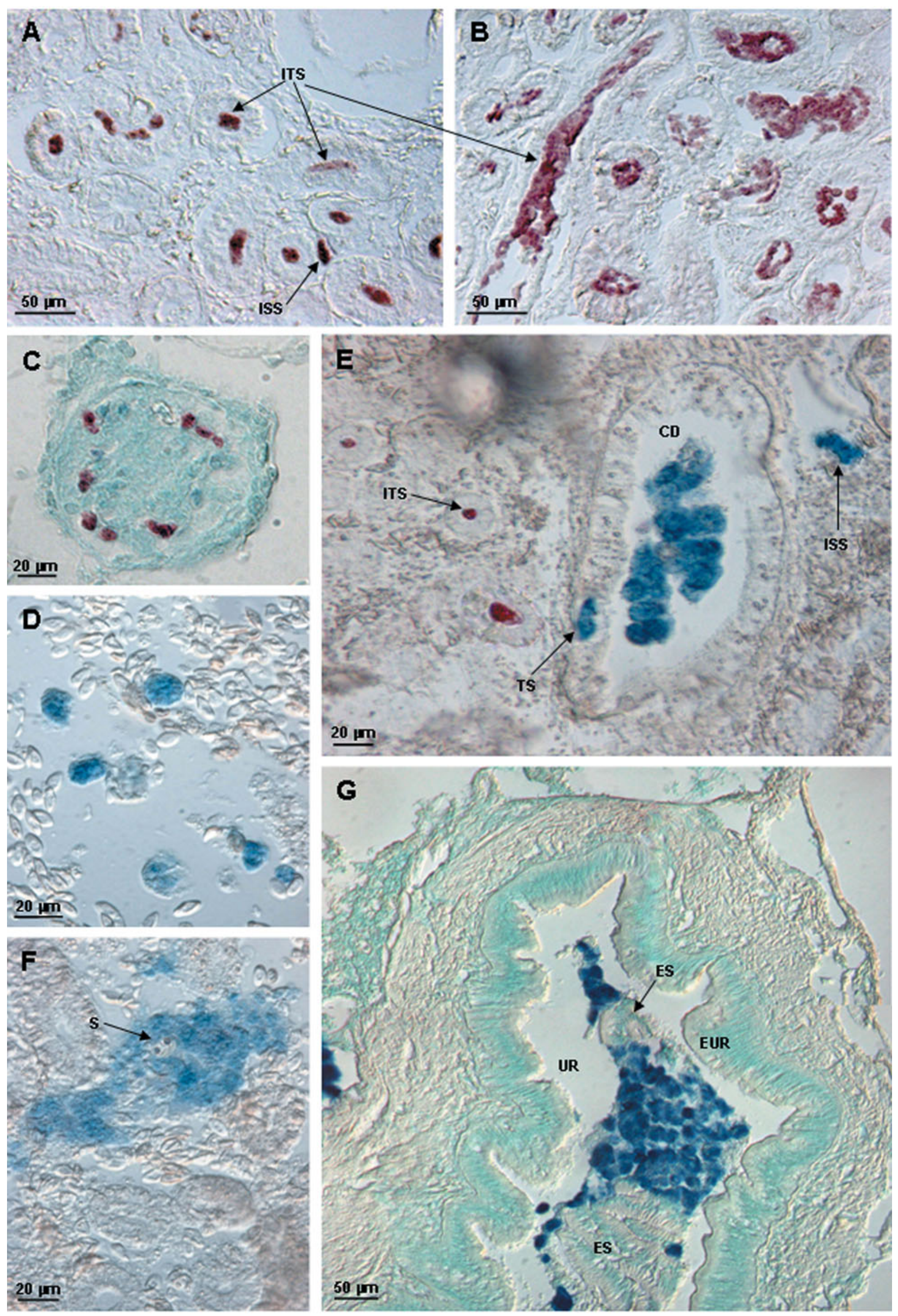

Fig. 3. For legend see opposite page. 
Table 2. Comparison of growth performance indicators of Atlantic cod fry originating from sites B and C, when cultured at $8{ }^{\circ} \mathrm{C}$ and $12{ }^{\circ} \mathrm{C}$, respectively, for 29 days (mean \pm standard deviation)

(Data were pooled for replicate tanks of the same site maintained at $8{ }^{\circ} \mathrm{C}$ where there were no statistical differences $(3$ tanks of site $\mathrm{B}$ and 2 tanks of site $\mathrm{C}) ; 12{ }^{\circ} \mathrm{C}$ tanks were not replicated and therefore not analysed statistically. SGR $=$ specific growth rate, $\mathrm{FCR}=$ food conversion ratio. ${ }^{*}$ Statistically significant differences between sites.)

\begin{tabular}{lcccc}
\hline \hline Site/Temperature & Site $\mathrm{B} / 8^{\circ} \mathrm{C}$ & Site $\mathrm{C} / 8{ }^{\circ} \mathrm{C}$ & Site $\mathrm{B} / 12{ }^{\circ} \mathrm{C}$ & Site $\mathrm{C} / 12{ }^{\circ} \mathrm{C}$ \\
\hline Number of fish analysed at end & 97 & 132 & 35 & 27 \\
Mean start weight (g) & $1 \cdot 04 \pm 0 \cdot 15$ & $0 \cdot 73 \pm 0 \cdot 12$ & $1 \cdot 04 \pm 0 \cdot 15$ & $0 \cdot 73 \pm 0 \cdot 12$ \\
Mean end weight (g) & $2 \cdot 32 \pm 0 \cdot 43^{*}$ & $1 \cdot 33 \pm 0 \cdot 35^{*}$ & $2 \cdot 62 \pm 0 \cdot 53$ & $1 \cdot 57 \pm 1 \cdot 00$ \\
Mean SGR & $2 \cdot 71 \pm 0 \cdot 63^{*}$ & $2 \cdot 00 \pm 0 \cdot 89 *$ & $3 \cdot 12 \pm 0 \cdot 73$ & $2 \cdot 48 \pm 1 \cdot 25$ \\
Mean FCR & $1 \cdot 14 \pm 0 \cdot 02^{*}$ & $2 \cdot 05 \pm 0 \cdot 18^{*}$ & $1 \cdot 27 \pm 0 \cdot 08$ & $2 \cdot 36 \pm 0 \cdot 19$ \\
Moribund fish + mortalities & 3 & 18 & 2 & 9 \\
\hline \hline
\end{tabular}

Table 3. Infection intensities = relative percentage of renal tubule sections infected with Gadimyxa atlantica per total number of tubule sections in 2 replicate histological sections per fish, before (start), during (moribund fish) and after (end) experimental 29 day growth trial of fry from Site B and Site $\mathrm{C}$ at $8{ }^{\circ} \mathrm{C}$ and at $12{ }^{\circ} \mathrm{C}$

(Data were pooled for replicate tanks of the same site maintained at $8{ }^{\circ} \mathrm{C}(3$ tanks of site $\mathrm{B}$ and 2 tanks of site C). Statistically significant differences between ${ }^{a}$ sites, ${ }^{\mathrm{b}}$ temperatures and ${ }^{\mathrm{c}}$ beginning and end of experimental period; moribund fish were not evaluated statistically due to low number of samples.)

\begin{tabular}{|c|c|c|c|c|}
\hline & $\begin{array}{l}\text { Infection } \\
\text { intensity start } \\
\text { Mean } \pm \text { S.D. } \\
\text { (range) }\end{array}$ & $\begin{array}{l}\text { Number of } \\
\text { moribund fish } \\
\text { during trial }\end{array}$ & $\begin{array}{l}\text { Infection } \\
\text { intensity of } \\
\text { moribund fish } \\
\text { Mean } \pm \text { s.D. }\end{array}$ & $\begin{array}{l}\text { Infection } \\
\text { intensity end } \\
\text { Mean } \pm \text { s.D. } \\
\text { (range) }\end{array}$ \\
\hline \multicolumn{5}{|l|}{$8^{\circ} \mathrm{C}$} \\
\hline Site B & $\begin{array}{l}8 \cdot 61 \pm 5 \cdot 49^{a} \\
(3 \cdot 17-19 \cdot 87)\end{array}$ & 2 & $16 \cdot 10 \pm 1 \cdot 41$ & $\begin{array}{l}19 \cdot 04 \pm 8 \cdot 75^{\mathrm{a}, \mathrm{b}, \mathrm{c}} \\
(6 \cdot 93-45 \cdot 38)\end{array}$ \\
\hline Site C & $\begin{array}{l}14 \cdot 45 \pm 6 \cdot 53^{a} \\
(7 \cdot 36-27 \cdot 32)\end{array}$ & 9 & $8 \cdot 09 \pm 5 \cdot 45$ & $\begin{array}{l}12 \cdot 78 \pm 6 \cdot 44^{\mathrm{a}} \\
(5 \cdot 75-29 \cdot 42)\end{array}$ \\
\hline \multicolumn{5}{|l|}{$12^{\circ} \mathrm{C}$} \\
\hline Site $B$ & $\begin{array}{l}8 \cdot 61 \pm 5 \cdot 49^{a} \\
(3 \cdot 17-19 \cdot 87)\end{array}$ & 1 & $23 \cdot 30 \pm 0 \cdot 00$ & $\begin{array}{l}27 \cdot 81 \pm 7 \cdot 88^{\mathrm{a}, \mathrm{b}, \mathrm{c}} \\
(17 \cdot 62-40 \cdot 77)\end{array}$ \\
\hline Site C & $\begin{array}{l}14 \cdot 45 \pm 6 \cdot 53^{a} \\
(7 \cdot 36-27 \cdot 32)\end{array}$ & 6 & $5 \cdot 81 \pm 2 \cdot 69$ & $\begin{array}{l}13 \cdot 39 \pm 6 \cdot 08^{\mathrm{a}} \\
(6 \cdot 86-27 \cdot 99)\end{array}$ \\
\hline
\end{tabular}

from site B performed significantly better than those from Site $\mathrm{C}$ both in terms of specific growth rate and food conversion ratio. Furthermore, the numbers of moribund and dead fish were considerably higher for Site C fry than for Site B fry. At the higher temperature of $12^{\circ} \mathrm{C}$ a substantially higher final weight and SGR of fry in both stocks was observed although, since the data were not replicated, no statistical analysis was carried out.

Percentage of parasite-infected renal tubule sections. The results of the parasite analysis are summarized in Table 3 . The percentage of infected tubule sections ranged from $3 \cdot 17 \%$ to $45 \cdot 38 \%$ (Table 3 ) in different individuals and varied greatly between the individuals from the same tank. In the pre-trial sample, cod fry from Site B had a significantly lower percentage of infected tubules $(8 \cdot 61 \%)$ than Site C fry (14.45\%). However, after 29 days, Site B fish showed significant proliferation of the parasite in terms of the percentage of infected tubule sections, up to a mean of $19.04 \%$ but, in contrast, there was no significant change in the Site $\mathrm{C}$ fry, (12.78\% tubule sections infected). The difference in the final parasite levels between Site B and C fry was highly significant.

Despite the better growth performance of fry in replicate tank 3 from Site B when compared with fry from the other 2 Site B replicate tanks, the proportion of infected tubules in fish from this tank was not significantly different from the other 2 replicates. In the heated tanks, the proportion of infected tubules in Site B fry was markedly higher after 29 days with a mean of $27 \cdot 81 \%$ tubules infected. In Site C fry-heated tanks there was little change from the levels recorded at the start of the experiment.

The number of moribund fish was considered to be too small for statistical analysis; however, examination of these fish demonstrated that the percentage of tubules infected was below the mean level for 
healthy fish originating from both sites at the end of the trial.

ISH showed that the myxozoan inside the tubules counted as 'infected tubules' in the experimental fish was exclusively $G$. atlantica. Individual presporogonic stages of $Z$. hildae were found in the interstitial tissue and blood vessels only in a small number of sections.

\section{DISCUSSION}

Mixed infections of the 2 renal myxozoans $G$. atlantica and $Z$. hildae were detected in cultured G. morhua sampled at 3 different hatcheries and at a tank-based research facility located on the west coast of Scotland. Two specific assays based on the $18 \mathrm{~S}$ rDNA sequence of the myxozoans, a single round PCR and a double-label ISH protocol were designed for $G$. atlantica and $Z$. hildae in this study. This permitted rapid, specific identification, visualization and localization of the 2 myxozoans in the same PCR reaction and on the same histological section, respectively. These methods proved to be invaluable tools to follow the development of the myxozoan infections in juvenile cod up to the age of 19 months. Possibly due to the lower number of cells and thus parasites in histological sections when compared with tissue samples taken for DNA extraction, and also due to the large copy number of $18 \mathrm{~S}$ rDNA tandem repeats per cell, resulting in a strong PCR signal despite low numbers of parasites, PCR detection was more sensitive than ISH. However, only the combination of both techniques allowed detection, in situ localization and identification of different life-cycle stages of the myxozoans.

G. atlantica was first described by Køie et al. (2007) who found $10 \%$ of Danish coastal cod and $50 \%$ of off-shore caught cod to be infected. However, in the present study, the infection prevalence of G. atlantica was $100 \%$. G. atlantica was most numerous in fry and juvenile cod whereas parasite numbers had decreased considerably in $1+$ G. morhua, despite their being reared in a continuously infectious environment. This decrease with age might explain the lower prevalences detected by Køie et al. (2007); their fish measured $21-76 \mathrm{~cm}$, equivalent to an age of 2-6 years in wild cod (Magnadóttir et al. 1999). The current study suggests that cod acquire immunity to $G$. atlantica since invasive blood stages were detected by PCR in $56 \%$ of 6 -month-old cod but had disappeared almost completely in fish older than 1 year although they were still in an infective environment. Acquired immunity to re-infection is mediated by lymphocytes and effected mainly through antibodies, a mechanism which takes 1-3 months depending predominantly on fish species and temperature (Magnadóttir, 2006). The ontogenetic development of the immune system of cod is very slow when compared with other marine species
(Magnadottir et al. 2005) and is not fully competent until 2-3 months after hatching (Schrøder et al. 1998; Magnadóttir et al. 2004). Thus, the development of a specific immune response in cod would occur at the age of approximately $3-5$ months. This coincides with our findings that only half of the 6-month-old cod presented G. atlantica blood stages and that blood stages had disappeared in $1+\operatorname{cod}$. Resistance to re-infection, based on acquired immunity and the production of specific antibodies, has been reported for various other myxozoans, including T. bryosalmonae (Saulnier and de Kinkelin, 1996), Enteromyxum spp. (Munoz et al. 2000, 2007; Sitja-Bobadilla et al. 2004, 2007), Myxobolus cerebralis Hofer, 1903 (Hedrick et al. 1998) and Myxobolus artus (Furuta et al. 1993). Intratubular sporogonic stages of $G$. atlantica in the renal tubules persisted in cod older than 2 years (Køie et al. 2007)). However, this does not contra-indicate acquired immunity to G. atlantica since persistence of sporogonic stages inside kidney tubules has also been observed in trout after acquiring immunity to T. bryosalmonae (Foott and Hedrick, 1987; Holzer et al. 2006). This might be due to spore production in an immunoprivileged coelozoic site (Sitja-Bobadilla, 2008).

The second myxozoan found in the kidney of $G$. morhua was $Z$. hildae which, in contrast to $G$. atlantica, has been described as a myxozoan species with low host specificity, occurring in various gadoid fish and showing a wide geographical range in the northern Atlantic and Pacific (Gaevskaya and Kovaleva, 1979; MacKenzie, 1979; Bakay and Zubchenko, 1981; Arthur, 1984; Aseeva, 2002; Køie et al. 2008).

Both $Z$. hildae and G. atlantica were found to produce blood stages in cod, indicating that both species use the blood as a medium of transport to the target organ, the kidney. The occurrence of blood stages of both $G$. atlantica and $Z$. hildae at all sites might indicate that they were continuously challenged by both species. Blood stages seem to be a common means of dissemination of myxosporean infections through the fish host. They were first described by Csaba (1976) and have subsequently been reported from all main phylogenetic clades of the myxosporea, e.g. T. bryosalmonae (Kent and Lom, 1986), Sphaerospora truttae Fischer-Scherl, ElMatbouli and Hoffmann, 1986 (McGeorge et al. 1994), Ceratomyxa shasta Noble, 1950 (Bartholomew et al. 1989) and S. renicola (reviewed by Lom and Dyková, 1992). It is therefore not surprising that more than 1 myxozoan occurs in the blood of an individual fish host at the same time. In brown trout, 4 myxozoans, i.e. Chloromyxum shurovi Shul'man \& Ieshko, 2003, T. bryosalmonae, S. truttae and Chloromyxum truttae Léger, 1906, occurred cotemporally in the blood (Holzer et al. 2006). In the current study, Z. hildae and G. atlantica blood stages 
were present at the same time in cod aged 6 months and they possibly co-occur in younger fry, for which no blood samples were analysed. All the 6-month-old cod and $62 \%$ of the $1+\operatorname{cod}$ tested PCR-positive for blood stages of $Z$. hildae. This indicates that, in contrast to $G$. atlantica, which was not found in the blood of $1+$ fish, $Z$. hildae is able to continuously invade and establish in cod at least up to the age of 19 months (oldest cod studied), and that specific immunity is not acquired or is only acquired at a later date.

$Z$. hildae showed massive proliferation in the blood of $1+\operatorname{cod}$, i.e. once $G$. atlantica had disappeared from the bloodstream. Similarly, the maximum $G$. atlantica spore-formation was detected in 3-month-old fry and spore numbers were still prominent in 6-month-old cod, whereas spore-formation of $Z$. hildae was only initiated in some of the 6 -month-old cod but spores were numerous in all $1+$ cod. This suggests that the presence of maximum numbers of blood stages and the proliferation and spore-formation of the 2 myxozoans in the kidney is separated in time, despite the fact that invasion by both $G$. atlantica and $Z$. hildae takes place in the smallest fry. Reciprocally varying prevalences with one species increasing in prevalence while another decreases, despite parallel transmission rates of both, strongly suggests within-host competition of the parasites (reviewed by Mideo, 2009). In the present case, there are 2 possible mechanisms for this: (1) a competitive advantage in resource acquisition may cause $G$. atlantica to proliferate and develop more rapidly and thus be more virulent than $Z$. hildae which, in contrast, takes more time to establish itself (exploitation competition), or (2) G. atlantica might directly suppress the development of $Z$. hildae using some type of allelopathy or even cross-reactive antibodies (interference competition). A number of studies have reported that different species of the malaria agent Plasmodium in human blood suppress each other in mixed-infected individuals (e.g. Bruce et al. 2000; Mayxay et al. 2001), which may be mediated by cross-reactive IgM (Nagao et al. 2008). Usually, the suppressed species rebounds after the other species has declined, and may appear as a prolonged infection (Richie, 1988). This general scheme has parallels with the progression of the infection with $G$. atlantica and $Z$. hildae observed in cod and might explain the chain of events. Competition between the parasites could also explain the spatial separation of the 2 myxozoans in the excretory system of the kidney with $G$. atlantica sporulating in the renal tubules and $Z$. hildae in the collecting ducts and ureters and, less frequently, in the interstitial tissue, as antagonistic interactions between parasitoids can be mediated by niche separation (Pedersen and Mills, 2004). For example sympatric, congeneric trematode species of Diplostomum have been shown to inhabit specific microhabitats in the avian intestine (Karvonen, $2006 a$ ) as well as different eye tissues of the fish host (Karvonen, 2006b).

The development of $G$. atlantica and $Z$. hildae might be strongly influenced by the maturation of the host's immune system parallel to the expansion of the infections and independently of the influence of the suggested interspecific competition on the development of the myxozoan infections. The ontogenetic development of the immune system of cod is not fully competent until 2-3 months after hatching (Schrøder et al. 1998; Magnadóttir et al. 2004) so that, prior to that, cod are wholly reliant on non-specific mechanisms for their defence against myxozoan infections.

The results of the growth study of fry originating from 2 different hatcheries are interesting because, during the experimental period, G. atlantica showed significant proliferation in fry from Site B but not in those from Site C. It would appear that the fry from Site $\mathrm{C}$ were able to mount an effective immune response against the parasite, thus preventing its proliferation. This may be related to the differences regarding the initial time and the duration of exposure to infective actinosporean stages of G. atlantica at the 2 sites. The alternate host of $G$. atlantica is an abundant spirorchid polychaete belonging to the genus Spirorbis (Køie et al. 2007). The actinosporean spores liberated by this invertebrate measure 7-8 $\mu \mathrm{m}$ (Køie, 2002) and thus Site B fry had established the first contact with $G$. atlantica infective stages at a later stage than Site $\mathrm{C}$ fry that had been maintained in $10 \mu \mathrm{m}$ filtered water and thus exposed to G. atlantica actinosporeans from the time of hatching onwards. Site B fry were on a $1 \mu \mathrm{m}$ filter for 58 days and only 29 days on unfiltered water prior to the experiment and may not have had time to develop an effective immune response to keep parasite numbers down during the experimental period.

It has been shown that increased temperatures allow myxozoans to proliferate more rapidly in both vertebrate and invertebrate hosts (Ferguson, 1981; Redondo et al. 2002; Yasuda et al. 2002; Foott et al. 2004; Sitja-Bobadilla et al. 2006; Tops et al. 2006). This might explain the higher infection load observed in site B fry sampled in summer (2007) and in winter (2008) (see Table 1). The elevated temperature resulted in greater proliferation only in the Site B fry and this might also reflect differences in the immune response, with site $\mathrm{C}$ fry being better able to control the parasite because of a greater immune competency.

Despite the heavy expansion of the $G$. atlantica infection in Site B fry, they showed a significantly better growth and lower mortality and, whilst this might be explained by their genetic differences, or better conditions during the earlier rearing period, it might also reflect the bioenergetic cost of maintaining immunity. The innate immune reactions as 
well as the adaptive responses have been shown to be energetically costly in a wide range of species from invertebrates, which rely exclusively on non-specific defence mechanisms, e.g. insects (Freitak et al. 2003) to vertebrates, e.g. fish (Beamish et al. 1996) or birds (Martin et al. 2003). The significantly lower growth rate in Site $\mathrm{C}$ fish may support the finding that infection generally leads to a hypermetabolic state to support up-regulation of the immune system (see review by Lochmiller and Deerenberg, 2000), here resulting in a greater proportion of the energy intake in the food being partitioned to immunoregulatory processes and repair than to growth. This is supported by the poorer food conversion ratio in the Site C fry.

A further explanation may be that more than 1 Gadimyxa species is present, and that the different species may be differentially pathogenic and the stocks have a predominance of one species. $G$. atlantica had been shown to occur in mixed infections with $G$. sphaerica in cod (Køie et al. 2007); however, in the current study, only 1 out of 72 clones was identified as G. sphaerica, indicating that $G$. atlantica is the dominant species at both sites and that species composition is not responsible for the differences observed between sites.

Overall, G. atlantica infection did not have a negative effect on the performance of Atlantic cod; there were no obvious pathological changes observed in the affected kidney tubules and it did not appear to contribute towards mortality in the growth study. Supporting this is the observation that the percentage of infected tubules in moribund fish was lower than in the healthy fish which was site independent. In contrast, $Z$. hildae was found to cause damage to the epithelium of the collecting ducts, induce localized macrophage invasion, and connective tissue proliferation in the walls of the collecting ducts of the kidney. Furthermore, a higher number of blood stages were present in the summer months than in the winter months indicating that host invasion and/ or pre-sporogonic proliferation was greater in summer, coinciding with the summer-time mortalities that occurred at Site D. However, the mild pathological changes observed, make it doubtful that the proliferation of the myxozoans was severe enough to be the exclusive cause of the observed mortalities but may have contributed amongst other factors, and thus further studies are needed.

According to the present knowledge, this is the first report that investigates the dynamics of a mixed myxozoan infection during the ontological development of the fish host. The results of the study strongly indicate the presence of within-host competition resulting in both, temporal and spatial separation of the infections during the host's development. As a future aim, it would be especially interesting to investigate the course of the 2 myxozoan infections independently and to try to isolate blood stages in order to investigate interactions in vitro. This could contribute considerably to our understanding of myxozoan interactions in their hosts, with the potential of using non-pathogenic species as biological control for pathogenic species.

F INANCIAL SUPPORT

This work was supported by the External Facilities of the University of Stirling (A.S.H. July-August 2007); by the Council of Education of the Valencian Autonomous Government (A.S.H. grant number GVPRE/2008/185) and by the Spanish Ministry of Science and Innovation (A.S.H. grant number JDCI2007-1054-1215).

\section{REFERENCES}

Arthur, J. R. (1984). A survey of the parasites of walleye pollock (Theragara chalcogramma) from the northeastern Pacific Ocean off Canada and a zoogeographical analysis of the parasite fauna of this fish throughout its range. Canadian Fournal of Zoology 62, 675-684.

Aseeva, N. L. (2002). Myxosporidian fauna from the Gadidae in Far Eastern seas. Parazitologiya 36, 167-174.

Bakay, Y. I. and Zubchenko, A. V. (1981). Parasites of roundnose grenadier (Coryphaenoides rupestris) in two areas of the north Atlantic in 1981. Annales Biologiques 38, 200-201.

Bartholomew, J. L., Smith, C. E., Rohover, J. S. and Fryer, J. L. (1989). Characterisation of a host response to the myxosporean parasite Ceratomyxa shasta (Noble), by histology, scanning electron microscopy and immunological techniques. Fournal of Fish Diseases 12, 509-522. doi : 10.1111/j.1365-2761.1989.tb00561.x.

Beamish, F. W. H., Sitja-Bobadilla, A., Jebbink, J. A. and Woo, P. T .K. (1996). Bioenergetic cost of cryptobiosis in fish: rainbow trout Oncorhynchus mykiss infected with Cryptobia salmositica and with an attenuated live vaccine. Diseases of Aquatic Organisms 25, 1-8. doi: 10.3354/dao025001.

Bruce, M. C., Donnelly, C. A., Alpers, M. P., Galinski, M. R., Barnwell, J. W., Walliker, D. and Day, K. P. (2000). Cross-species interactions between malaria parasites in humans. Science 287, 845-848. doi: 10.1126/science.287.5454.845.

Csaba, S. (1976). An unidentifiable extracellular sporozoan parasite from the blood of the carp. Parasitologia Hungarica 9, 21-24.

Feist, S. W., Peeler, E. J., Gardiner, R., Smith, E. and Longshaw, M. (2002). Proliferative kidney disease and renal myxosporidiosis in juvenile salmonids from rivers in England and Wales. Fournal of Fish Diseases 25, 451-458. doi : 10.1046/j.1365-2761.2002.00361.x.

Ferguson, H. W. (1981). The effects of water temperature on the development of proliferative kidney disease in rainbow trout, Salmo gairdneri Richardson. Fournal of Fish Diseases 4, 175-177. doi: 10.1017/ S0031182009005800.

Foott, J. S., Harmon, R. and Stone, R. (2004). Effect of water temperature on non-specific immune function and ceratomyxosis in juvenile chinook salmon and steelhead from the Klamath River. California Fish and Game 90, 71-84. 
Foott, J. S. and Hedrick, R. P. (1987). Seasonal occurrence of the infectious stage of proliferative kidney disease (PKD) and resistance of rainbow trout, Salmo gairdneri Richardson, to reinfection. Fournal of Fish Biology 30, 477-483. doi : 10.1111/j.10958649.1987.tb05771.x.

Freitak, D., Ots, I., Vanatoa, A. and Horak, P. (2003). Immune response is energetically costly in white cabbbage butterfly pupae. Proceedings of the Royal Society of London, B 270 (Suppl.) S220-S222. doi: 10.1098/rsbl.2003.0069.

Furuta, T., Ogawa, K. and Wakabayashi, H. (1993). Humoral immune response of carp Cyprinus carpio to Myxobolus artus (Myxozoa, Myxobolidae) infection. Fournal of Fish Biology 43, 441-450. doi: 10.1111/ j.1095-8649.1993.tb00579.x.

Gaevskaya, A. V. and Kovaleva, A. A. (1979). New and rarely occurring myxosporidia species from the Celtic Sea fishes. Parazitologiya 13, 159-165.

Hedrick, R. P., El Matbouli, M., Adkison, M. A. and MacConnell, E. (1998). Whirling disease: reemergence among wild trout. Immunological Reviezs 166, 365-376. doi: 10.1111/j.1600-065X.1998. tb01276.x.

Holzer, A. S., Sommerville, C. and Wootten, R. (2003). Tracing the route of Sphaerospora truttae from the entry locus to the target organ of the host, Salmo salar L., using an optimized and specific in situ hybridization technique. Fournal of Fish Diseases 26, 647-655. doi: 10.1046/j.13652761.2003.00501.x.

Holzer, A. S., Sommerville, C. and Wootten, R. (2004). Molecular relationships and phylogeny in a community of myxosporeans and actinosporeans based on their 18S rDNA sequences. International Fournal for Parasitology 34, 1099-1111. doi: 10.1016/ j.ijpara.2004.06.002.

Holzer, A. S., Sommerville, C. and Wootten, R. (2006). Molecular studies on the seasonal occurrence and development of five myxozoans in farmed Salmo trutta L. Parasitology 132, 193-205. doi : 10.1017/ S0031182005008917.

Holzer, A. S., Wootten, R. and Sommerville, C. (2010). Zschokkella hildae Auerbach, 1910: Phylogenetic position, morphology, and location in cultured Atlantic cod. Parasitology International (in the Press) doi:10.1016/j.parint.2009.12.004.

Jones, S. R. M., Prosperi-Porta, G., Dawe, S. C. and Barnes, D. P. (2003). Distribution, prevalence and severity of Parvicapsula minibicornis infections among anadromous salmonids in the Fraser River, British Columbia, Canada. Diseases of Aquatic Organisms 54, 49-54. doi: 10.3354/dao054049.

Karvonen, A. (2006a). Intestinal distribution and fecundity of two species of Diplostomum parasites in definitve hosts. Parasitology 132, 357-362. doi: $10.1017 / \mathrm{S} 0031182005009091$.

Karvonen, A. (2006b). Ecological divergence of closely related Diplostomum (Trematoda) parasites. Parasitology 133, 229-235. doi : 10.1017/ S0031182006000242.

Kent, M. L. and Lom, J. (1986). Development of the PKX myxosporean in rainbow trout Salmo gairdneri. Diseases of Aquatic Organisms 1, 159-182.
Køie, M. (2002). Spirorchid and serpulid polychaetes are candidates as invertebrate hosts for myxozoa. Folia Parasitologica 49, 160-162.

Køie, M., Karlsbakk, E. and Nylund, A. (2007). A new genus Gadimyxa with three new species (Myxozoa, Parvicapsulidae) parasitic in marine fish (Gadidae) and the two-host life cycle of Gadimyxa atlantica n.sp. Fournal of Parasitology 93, 1456-1467. doi: 10.1645/GE-1256.1.

Køie, M., Steffensen, J. F., Moller, P. R. and Christiansen, J. S. (2008). The parasite fauna of Arctogadus glacialis (Peters) (Gadidae) from western and eastern Greenland. Polar Biology 31, 1017-1021. doi: 10.1007/s00300-008-0440-1.

Lochmiller, R. L. and Deerenberg, C. (2000). Tradeoffs in evolutionary immunology : just what is the cost of immunity? Oikos 88, 87-98. doi: 10.1034/j.16000706.2000.880110.x.

Lom, J. and Dyková, I. (1992). Myxosporidia (Phylum Myxozoa). In Protozoan Parasites of Fishes (ed. Lom, J. and Dyková, I.), pp. 159-315. Elsevier Science Publishers B.V.

Lom, J. and Dyková, I. (2006). Myxozoan genera: definition and notes on taxonomy, life-cycle terminology and pathogenic species. Folia Parasitologica 53, 1-36.

MacKenzie, K. (1979). Some parasites and diseases of blue whiting Micromesistius poutassou to the north and west of Scotland and at the Faroe Islands UK. Scottish Fisheries Research Report 1-14.

Magnadóttir, B. (2006). Innate immunity of fish (overview). Fish $\Xi$ Shellfish Immunology 20, 137-151. doi: 10.1016/j.fsi.2004.09.006.

Magnadóttir, B., Jonsdottir, H., Helgason, S., Bjornsson, B., Jorgensen, T. O. and Pilstrom, L. (1999). Humoral immune parameters in Atlantic cod (Gadus morhua L.) - I. The effects of environmental temperature. Comparative Biochemistry and Physiology B-Biochemistry \& Molecular Biology 122, 173-180. doi: 10.1016/S0305-0491(98)10156-6.

Magnadóttir, B., Lange, S., Gudmundsdottir, S., Bogwald, J. and Dalmo, R. A. (2005). Ontogeny of humoral immune parameters in fish. Fish $\mathbb{E}^{\circ}$ Shellfish Immunology 19, 429-439.

Magnadóttir, B., Lange, S., Steinarsson, A. and Gudmundsdottir, S. (2004). The ontogenic development of innate immune parameters of cod (Gadus morhua L.). Comparative Biochemistry and Physiology B - Biochemistry \& Molecular Biology 139, 217-224.

Martin, L. B., Scheuerlein, A. and Wikelski, M. (2003). Immune activity elevates energy expenditure of house sparrows: a link between direct and indirect costs? Proceedings of the Royal Society of London, B 270, 153-158. doi: 10.1098/rspb.2002.2185.

Mayxay, M., Pukrittayakamee, S., Chotivanich, K., Imwong, M., Looareesuwan, S. and White, N. J. (2001). Identification of cryptic co-infection with Plasmodium falciparum in patients presenting with vivax malaria. American Fournal of Tropical Medicine and Hygiene 65, 588-592.

McGeorge, J., Sommerville, C. and Wootten, R. (1994). Light and electron-microscope observations on extrasporogonic and sporogonic stages of a myxosporean parasite of the genus Sphaerospora Thelohan, 1892 from 
Atlantic salmon, Salmo salar L. in Scotland. Fournal of Fish Diseases 17, 227-238. doi: 10.1111/j.13652761.1994.tb00218.x.

Mideo, N. (2009). Parasite adaptations to within-host competition. Trends in Parasitology 25, 261-268. doi: 10.1016/j.pt.2009.03.001.

Munoz, P., Cuesta, A., Athanassopoulou, F., Golomazou, H., Crespo, S., Padros, F., SitjaBobadilla, A., Albinana, G., Esteban, M. A., Alvarez-Pellitero, P. and Meseguer, J. (2007). Sharpsnout sea bream (Diplodus puntazzo) humoral immune response against the parasite Enteromyxum leei (Myxozoa). Fish E Shellfish Immunology 23, 636-645. doi: 10.1016/j.fsi.2007.01.014.

Munoz, P., Sitja-Bobadilla, A. and Alvarez-Pellitero, P. (2000). Cellular and humoral immune response of European sea bass (Dicentrarchus labrax L.) (Teleostei: Serranidae) immunized with Sphaerospora dicentrarchi (Myxosporea: Bivalvulida). Parasitology 120, 465-477.

Nagao, Y., Kimura-Sato, M., ChavalitshewinkoonPetmitr, P., Thongrungkiat, S., Wilairatana, P., Ishida, T., Tan-Ariya, P., de Souza, J. B., Krudsood, S. and Looareesuwan, S. (2008). Suppression of Plasmodium falciparum by serum collected from a case of Plasmodium vivax infection. Malaria Fournal 7, 113. doi : 10.1186/14752875-7-113.

Pedersen, B. S. and Mills, N. J. (2004). Single vs. multiple introduction in biological control: the roles of parasitoid efficiency, antagonism and niche overlap. Fournal of Applied Ecology 41, 973-984. doi: 10.1111/ j.0021-8901.2004.00953.x.

Redondo, M. J., Palenzuela, O., Riaza, A., Macias, A. and Alvarez-Pellitero, P. (2002). Experimental transmission of Enteromyxum scophthalmi (Myxozoa), an enteric parasite of turbot Scophthalmus maximus. Fournal of Parasitology 88, 482-488. doi: 10.1645/00223395(2002)088[0482:ETOESM]2.0.CO;2.

Richie, T. L. (1988). Interactions between malaria parasites infecting the same vertebrate host. Parasitology 96, 607-639.

Saulnier, D. and de Kinkelin, P. (1996). Antigenic and biochemical study of PKX, the myxosporean causative agent of proliferative kidney disease of salmonid fish. Diseases of Aquatic Organisms 27, 103-114.

Schrøder, M. B., Villena, A. J. and Jorgensen, T. O. (1998). Ontogeny of lymphoid organs and immunoglobulin producing cells in Atlantic cod (Gadus morhua L.). Developmental and Comparative Immunology 22, 507-517. doi: 10.1016/S0145-305X(98)00030-5.

Sitja-Bobadilla, A. (2008). Living off a fish: A trade-off between parasites and the immune system. Fish $\mathcal{E}^{\circ}$ Shellfish Immunology 25, 358-372. doi : 10.1016/ j.fsi.2008.03.018.

Sitja-Bobadilla, A., Palenzuela, O., Riaza, A., Macias, M. A. and Alvarez-Pellitero, P. (2007). Protective acquired immunity to Enteromyxum scophthalmi (myxozoa) is related to specific antibodies in Psetta maxima (L.) (teleostei). Scandinavian Fournal of Immunology 66, 26-34. doi: 10.1111/ j.1365-3083.2007.01942.x.

Sitja-Bobadilla, A., Redondo, M. J., Bermudez, R., Palenzuela, O., Ferreiro, I., Riaza, A., Quiroga, I., Nieto, J. M. and Alvarez-Pellitero, P. (2006). Innate and adaptive immune responses of turbot, Scophthalmus maximus (L.), following experimental infection with Enteromyxum scophthalmi (Myxosporea: Myxozoa). Fish \& Shellfish Immunology 21, 485-500.

Sitja-Bobadilla, A., Redondo, M. J., Macias, M. A., Ferreiro, I., Riaza, A. and Alvarez-Pellitero, $P$. (2004). Development of immunohistochemistry and enzyme-linked immunosorbent assays for the detection of circulating antibodies against Enteromyxum scophthalmi (Myxozoa) in turbot (Scophthalmus maximus L.). Fish \& Shellfish Immunology 17, 335-345.

St Hilaire, S., Boichuk, M., Barnes, D., Higgins, M., Devlin, R., Withler, R., Khattra, J., Jones, S. and Kieser, D. (2002). Epizootiology of Parvicapsula minibicornis in Fraser River sockeye salmon, Oncorhynchus nerka (Walbaum). Fournal of Fish Diseases 25, 107-120.

Tops, S., Lockwood, W. and Okamura, B. (2006). Temperature-driven proliferation of Tetracapsuloides bryosalmonae in bryozoan hosts portends salmonid declines. Diseases of Aquatic Organisms 70, 227-236. doi: 10.3354/dao070227.

Wahli, T., Knuesel, R., Bernet, D., Segner, H., Pugovkin, D., Burkhardt-Holm, P., Escher, M. and Schmidt-Posthaus, H. (2002). Proliferative kidney disease in Switzerland: current state of knowledge. Fournal of Fish Diseases 25, 491-500. doi: 10.1046/ j.1365-2761.2002.00401.x.

Yasuda, H., Ooyama, T., Iwata, K., Tun, T., Yokoyama, H. and Ogawa, K. (2002). Fish-to-fish transmission of Myxidium spp. (Myxozoa) in cultured tiger puffer suffering from emaciation disease. Fish Pathology 37, 29-33. 